\title{
IDENTIFIKASI JENIS SERANGGA HAMA DAN TINGKAT KERUSAKAN PADA Diospyros Celebica Bakh.
}

\author{
IDENTIFICATION OF TYPES OF PEST INTEREST AND LEVEL OF DAMAGE IN Diospyros \\ Celebica Bakh.
}

\author{
Hendra Susanto Mokodompit'), Hard N. Pollo²), dan Marthen T. Lasut ${ }^{2}$ \\ 1)Mahasiswa S1 Program Studi Ilmu Kehutanan, Fakultas Pertanian Unsrat Manado, 95115 \\ 2)Staf Pengajar PS. IImu Kehutanan Jurusan Budidaya Pertanian, Fakultas Pertanian Unsrat Manado, 95115
}

\begin{abstract}
Diospyros celebica Bakh is luxury wood which is endemic to Sulawesi. The Environment and Forestry Research and Development Istitute of Manado is implementing an ex situ conservation of $D$. celebica through planting it in The Arboretum since 2012. The D. celebica stand at the BP2LHK Arboretum in Manado was attacked by insects on the leaves, the leaf part is gnawed from the edge to the vein and midrib. The purpose of this study is to identify the types of insects which is pest to leaves of $D$ celebica and calculate the level of damage caused. The study was conduct on the plot of $D$. celebica stands by census observation. Two types of insects were identified, namely leaf cutting bees (Megachile $s p$ ) and caterpillars from the order of Lepidoptera. The main insects that damage the leaves of $D$. celebica is leaf-cutting bee (Megachile $s p$ ) because this insect has no natural predators. The caterpillars of the order lepidóptera have a number of natural predators, such as Pycnonotus aurigaster, Centropus bengalensis, Phaenicophaeus calyorhynchus, Hypothymis azurea, and Oecophylla smaragdina. The results showed that the frequency of insect attacks on D. celebica leaves was $97.44 \%$, there are 38 of 39 plant observed were attacked by insect. The intensity of insect attacks on stands of $D$. celebica is $11.54 \%$, this result shows that pest control in stands is not yet necessary, since of the intensity of the attack is including minor damage.
\end{abstract}

Keywords: insect, pests, Diospyros celebica Bakh., Intensity of damage

\begin{abstract}
ABSTRAK
Diospyros celebica Bakh. merupakan salah satu kayu mewah endemik Sulawesi. Balai Penelitian dan Pengembangan Lingkungan Hidup dan Kehutanan Manado melaksanakan konservasi secara eksitu jenis $D$. celebica dengan penanaman di Arboretum sejak tahun 2012. Tegakan D. celebica di Arboretum BP2LHK Manado diserang serangga pada daun, bagian daun digerogoti mulai dari tepi sampai tulang daun. Tujuan penelitian ini adalah mengidentifikasi jenis-jenis serangga yang menyerang daun $D$ celebica dan menghitung tingkat kerusakan.. Penelitian dilakukan pada plot tegakan $D$. celebica dengan pengamatan secara sensus. Teridentifikasi 2 jenis serangga hama yaitu lebah pemotong daun (Megachile sp) dan ulat bulu dari ordo Lepidóptera. Serangga utama yang merusak daun $D$. celebica adalah lebah pemotong daun (Megachile sp) karena serangga ini tidak memiliki predator alami. Ulat bulu dari ordo Lepidóptera, famili Erebidae, sub famili Arctinae memiliki beberapa predator alami yaitu cucak kutilang (Pycnonotus aurigaster), bubut alang-alang (Centropus bengalensis), kadalan Sulawesi (Phaenicophaeus calyorhynchus), kehicap ranting (Hypothymis azurea), dan semut rangrang (Oecophylla smaragdina). Hasil penelitian menunjukkan frekuensi serangan serangga pada daun $D$. celebica sebesar $97,44 \%$ dimana dari 39 tanaman yang diamati terdapat 38 tanaman yang diserang hama serangga. Intensitas serangan hama serangga pada tegakan $D$. celebica sebesar $11,54 \%$, hasil ini menunjukkan belum perlu dilakukan penanggulangan hama pada tegakan karena intensitas serangan termasuk rusak ringan.
\end{abstract}

Kata kunci : serangga hama, Diospyros celebica Bakh., intensitas kerusakan 


\section{PENDAHULUAN}

Diospyros celebica Bakh (Ebenaceae) merupakan penghasil kayu eboni yang memiiki nilai artistik tinggi karena motifnya yang sangat indah, hal tersebut menjadikan nilai jualnya sangat tinggi. Kayu eboni digunakan sebagai bahan baku mebel, bahan bangunan, kayu lapis mewah dan bahan kerajinan. D. celebica merupakan salah satu kayu mewah endemik Sulawesi, eksploitasi telah berlangsung sejak abad ke-18. Dampak dari eksplotasi secara besar-besaran pada masa lalu menyebabkan ancaman kelangkaan bahkan kepunahan pada tingkat spesies maupun genetiknya. (Kinho, 2014).

Balai Penelitian Kehutanan Manado pada tahun 2010-2013 melaksanakan kegiatan eksplorasi Diospyros spp. di beberapa tempat yaitu Cagar Alam Tangkoko, pulau Talise, Taman Nasional Bogani Nani Wartabone, Maros Sulawesi Selatan, pulau Halmahera. Tujuan dari eksplorasi ini adalah untuk melakukan konservasi secara ek-situ jenis Diospyros. Kegiatan eksplorasi di lanjutkan dengan penanaman di Arboretum Balai Penelitian Kehutanan Manado pada tahun 2012.

Observasi awal di Arboretum BP2LHK Manado, jenis $D$. celebica diserang serangga pada bagian daun. Daun digerogoti mulai dari tepi sampai tulang daun dengan bentuk serangan membulat. Serangan serangga pada daun bisa mengakibatkan rontoknya daun $D$. celebica.

Peranan serangga sangat penting bagi ekosistem, peranan tersebut dapat menguntungkan atau merugikan. Peran menguntungkan diantaranya sebagai polinator, dekomposer, berperan sebagai musuh alami serangga lain. Peran serangga yang merugikan dapat menyebabkan kerusakan pada tanaman seperti daun, batang dan buah. Serangga yang menimbulkan kerusakan pada tanaman dan menyebabkan kerugian dikategorikan sebagai hama.

Serangan serangga pada daun $D$. celebica dapat merusak tanaman terutama serangga dari kelompok defoliator. Serangga yang menyerang daun $D$. celebica belum diketahui jenisnya sehingga tindakan kuratif belum bisa dilakukan. Terbatasnya informasi mengenai jenis serangga hama pada $D$. celebica membuat penulis tertarik melakukan penelitian ini.

Penelitian ini bertujuan untuk mengetahui jenis-jenis serangga yang menyerang daun $D$ celebica dan menghitung tingkat kerusakan yang disebabkan. Manfaat dari penelitian ini adalah diketahuinya jenis serangga yang menyerang daun $D$ celebica dan tingkat kerusakan yang disebabkan sehingga dapat diambil langkah yang tepat dalam upaya pengendalian hama.

\section{METODE PENELITIAN}

Penelitian dilaksanakan pada bulan Juni 2018 di Arboretum Balai Penelitian dan Pengembangan Lingkungan Hidup dan Kehutanan Manado pada plot $D$. celebica dengan luas $625 \mathrm{~m}^{2}$.

Alat yang digunakan dalam penelitian adalah : killing botol, jaring serangga, bBotol koleksi serangga, kamera, Termohigrometer dan GPS.

Bahan yang digunakan dalam penelitian ini adalah : serangga, kertas label, buku kunci determinasi serangga, alat tulis dan alkohol $70 \%$.

Pengamatan dilakukan pada plot tegakan D. celebica yang terdiri dari 39 pohon secara visual, semua tanaman diamati khususnya pada bagian daun yang diserang serangga. Pengambilan data dengan cara : 1) Menangkap serangga yang menyerang daun pada tegakan $D$. celebica, 2) Identifikasi jenis serangga, 3) Menghitung frekuensi serangan, 4) Menghitung intensitas serangan, 5) Keadaan umum lokasi penelitian yang meliputi letak topografi, suhu, kelembaban, 6) Penilaian serangan serangga pada daun $D$. celebica yaitu setiap pohon dibagi menjadi 3 bagian yaitu tajuk atas, tajuk tengah dan tajuk bawah. Setiap tajuk dibagi lagi menjadi 3 bagian yaitu daun di ujung cabang, tengah cabang dan pangkal cabang. Gejala serangan berdasarkan skor 0 sampai 4 .

\section{Analisis Data}

Identifikasi jenis serangga berpedoman pada kunci determinasi serangga, perhitungan frekuensi ditemukannya serangga yang menyerang daun $D$ celebica

$$
F=\frac{S}{\text { R }} \times 100 \%
$$


$\mathrm{F}$ : Frekuensi ditemukannya serangga

$S$ : Jumlah pohon ditemukannya serangga

$\mathrm{R}$ : Jumlah seluruh pohon yang diamati Intensitas serangan (IS) dihitung dengan menggunakan rumus menurut Singh dan Mishra (1992) yang dilakukan perubahan model rumusnya oleh (Mardji, 2000; Tribowo, et. al., 2014) sebagai berikut :

$$
I S=\frac{X_{1} Y_{1}+X_{2} Y_{2}+X_{3} Y_{3}+X_{4} Y_{4}}{X Y} \times 100 \%
$$

IS : Intensitas serangan

$X$ : Jumlah pohon yang diamati

$Y$ : Jumlah kriteria skor (4)

$X_{1}$ : Jumlah pohon yang terserang ringan (skor 1)

$X_{2}$ :Jumlah pohon yang terserang sedang (skor 2)

$\mathrm{X}_{3}$ : Jumlah pohon yang terserang berat (skor 3 )

$\mathrm{X}_{4}$ : Jumlah pohon yang mati (skor 4 )

$Y_{1}$ : Nilai 1 dengan kriteria terserang ringan

$\mathrm{Y}_{2}$ : Nilai 2 dengan kriteria terserang sedang
$Y_{3}$ : Nilai 3 dengan kriteria terserang berat

$Y_{4}$ : Nilai 4 dengan kriteria mati atau tidak ada tanda-tanda kehidupan

Kriteria dan skor untuk serangan pada setiap tanaman (Mardji, 2000; Tribowo, et.al., 2014) dapat dilihat pada Tabel 1.

Menentukan kondisi pohon secara keseluruhan berdasarkan intensitas serangan (Mardji, 2003; Tribowo, 2014) dapat dilihat pada Tabel 2.

Menghitung frekuensi serangan $(P)$ dihitung dengan membandingkan jumlah pohon yang terserang dengan jumlah pohon secara keseluruhan dinyatakan dalam (\%). Rumus yang digunakan sebagai berikut :

$$
\begin{aligned}
& P=\stackrel{Y}{X} \text {--- } \times 100 \% \\
& P: \text { Frekuensi serangan } \\
& Y \text { : Jumlah pohon yang terserang } \\
& X: \text { Jumlah pohon yang diamati }
\end{aligned}
$$

Tabel 1. Cara Menentukan Nilai/Skor Serangan pada Setiap Tanaman

(Table 1. How to Determine the Attack Value /Score for Each Plant)

\begin{tabular}{clc}
\hline Kriteria & \multicolumn{1}{c}{ Gejala Serangan } & Skor \\
\hline Sehat & $\begin{array}{l}\text { Tidak ada serangan atau ada serangan pada daun tetapi jumlah daun yang } \\
\text { terserang dan luas serangan sangat kecil dibandingkan jumlah/luas seluruh } \\
\text { daun }\end{array}$ & 0 \\
Terserang ringan & $\begin{array}{l}\text { Jumlah daun yang terserang sedikit dan jumlah serangan pada masing- } \\
\text { masing daun yang terserang sedikit atau daun rontok atau klorosis sedikit }\end{array}$ & 1 \\
Terserang sedang & $\begin{array}{l}\text { Jumlah daun yang terserang dan jumlah serangan pada masing-masing } \\
\text { daun yang terserang agak banyak atau daun rontok atau klorosis agak } \\
\text { banyak } \\
\text { Terserang berat }\end{array}$ & $\begin{array}{l}\text { Jumlah daun yang terserang dan jumlah daun serangan masing-masing } \\
\text { daun yang terserang banyak atau daun rontok atau klorosis banyak }\end{array}$ \\
\hline Mati & Seluruh daun rontok atau tidak ada tanda-tanda kehidupan & 3 \\
\hline
\end{tabular}

Tabel 2. Cara Menentukan Kondisi Keseluruhan Pohon Berdasarkan Intensitas Serangan

(Table 2. How to Determine the Overall Condition of Trees Based on Attack Intensity)

\begin{tabular}{cc}
\hline Intensitas serangan (\%) & Kondisi Tegakan \\
\hline $0-1$ & Sehat (S) \\
$>1-25$ & Rusak Ringan (RR) \\
$>25-50$ & Rusak Sedang (RS) \\
$>50-75$ & Rusak Berat (RB) \\
$>75-100$ & Rusak Sangat Berat (RT) \\
\hline
\end{tabular}




\section{HASIL DAN PEMBAHASAN}

\section{Keadaan Umum Lokasi Penelitian}

Lokasi penelitian bertempat di Arboretum

Balai Penelitian dan Pengembangan Lingkungan Hidup dan Kehutanan (BP2LHK) Manado. Plot Diospyros celebica mempunyai luas $625 \mathrm{~m}^{2}$ dengan jarak tanam $3 \times 3$ meter dan jumlah tanaman yang diamati sebanyak 39 tanaman. Titik koordinat lokasi penelitian N 1033'42.1" E 124054'11.6" Suhu pada plot penelitian $290 \mathrm{c}$, kelembaban $56 \%$. Kondisi lingkungan sekitar di sebelah utara adalah kandang anoa, sebelah timur arboretum dan perumahan karyawan, sebelah selatan perkebunan masyarakat, sebelah barat arboretum dan persemaian permanen.

Diospyros celebica di Arboretum BP2LHK Manado ditanam pada tanggal 26 April 2012. Tinggi pohon 4,4 sampai $7,4 \mathrm{~m}$ dengan diameter 3,8 sampai $9,6 \mathrm{~cm}$. Tinggi bebas cabang 1,5 sampai $2,9 \mathrm{~m}$. Hasil pengukuran dapat dilihat bahwa tegakan $D$. celebica berada pada tingkat pancang.

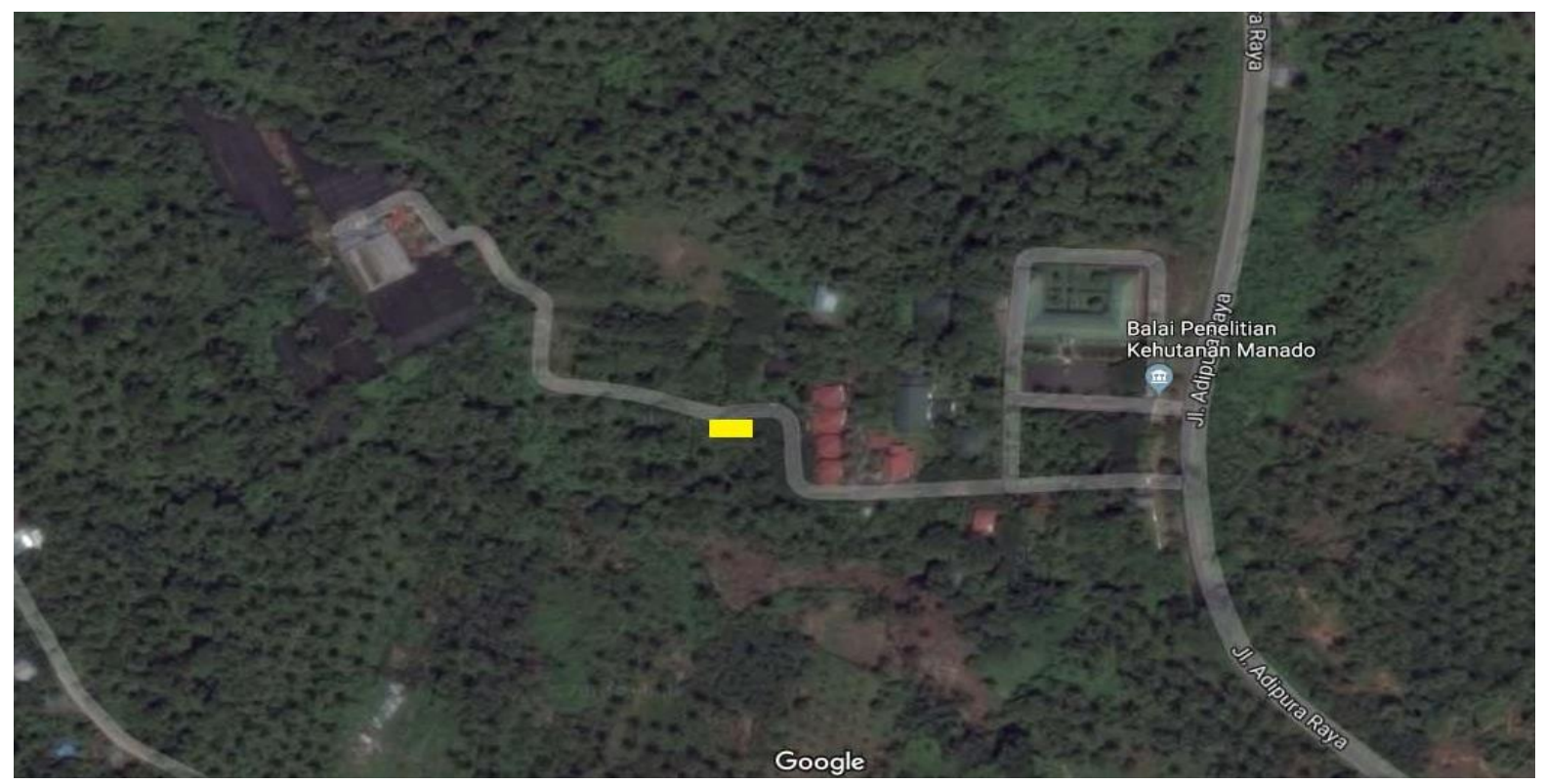

Gambar 1. Peta Lokasi Penelitian

(Figure 1. Map of the Research Location)
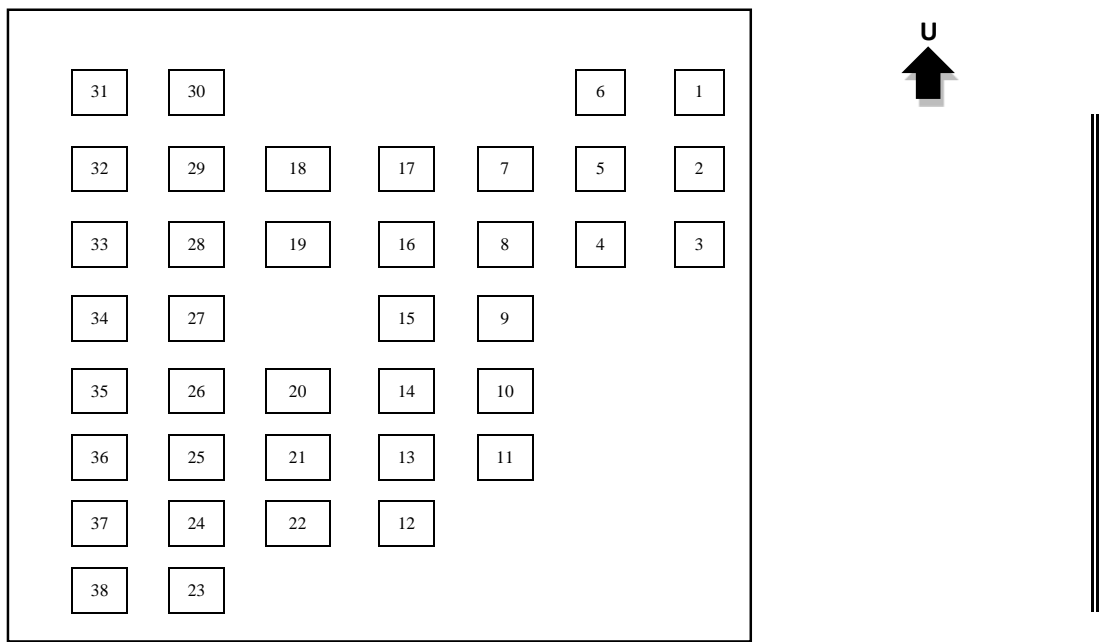

Gambar 2. Penyebaran Pohon

(Figure 2. Tree Spread) 


\section{Serangga Pada Tegakan Diospyros celebica}

Jenis-jenis serangga yang ditemukan pada tegakan $D$. Celebica dapat dilihat pada Tabel 3 .

Berdasarkan hasil pengamatan langsung dilapangan ditemukan 3 ordo yang terdiri dari 5 jenis serangga, dari 5 jenis serangga tersebut yang merusak daun $D$. celebica adalah lebah pemotong daun (Megachile sp) dan ulat bulu (Ordo Lepidoptera).

\section{Lebah Pemotong Daun (Megachile sp)}

Klasifikasi diuraikan sebagai berikut

$\begin{array}{lll}\text { Golongan } & : & \text { Animalia } \\ \text { Phylum } & : & \text { Arthropoda } \\ \text { Klas } & : & \text { Insekta } \\ \text { Ordo } & : & \text { Hymenoptera } \\ \text { Famili } & : & \text { Megachilidae } \\ \text { Genus } & : & \text { Megachile } \\ \text { Spesies } & : & \text { Megachile sp }\end{array}$

Ciri-ciri serangga ini adalah sebagai berikut : panjang tubuh $2 \mathrm{~cm}$ dan lebar $1 \mathrm{~cm}$, mata hampir mencapai pangkal mandibular, mempunyai sepasang antena dan antena lebih pendek dari tubuhnya, antena terdiri atas 12 ruas (betina) atau 13 ruas (jantan), tipe alat mulut pemotong penghisap, lidah sedikit memanjang dan meruncing, mempunyai dua pasang sayap bersifat membran dengan panjang $1 \mathrm{~cm}$ jika kedua sayap dibentangkan mencapai panjang $3 \mathrm{~cm}$, sayap belakang lebih kecil daripada sayap depan, agak bertubuh padat, abdomen bersambung dengan thoraks dengan sebuah ruas yang ramping, mempunyai tiga pasang kaki, tarsi lima ruas, ruas pertama tarsi kaki belakang agak memanjang dan memipih, tibia kaki belakang dengan runcingan pada ujungnya

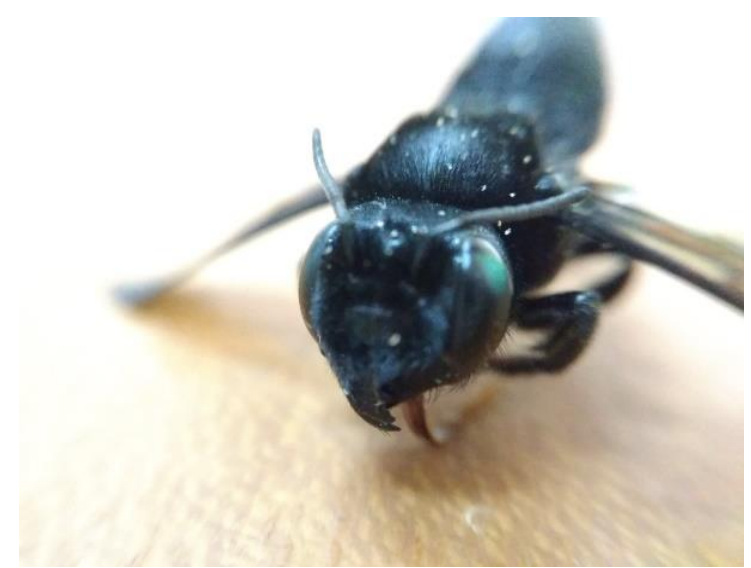

Gambar 3. Lebah Megachile sp (tampak depan)

(Figure 3. Megachile sp Bee (front view))

Tabel 3. Jenis-Jenis Serangga yang Ditemukan pada Tegakan D. celebica.

(Table 3. Types of Insects Found in D. celebica Stands)

\begin{tabular}{cllc}
\hline No. & \multicolumn{1}{c}{ Ordo } & \multicolumn{1}{c}{ Jenis Serangga } & Keterangan \\
\hline 1. & Orthoptera & Belalang (Valanga nigricornis) & Imago \\
2. & Orthoptera & Jangkrik (Gryllus $\mathrm{sp})$ & Imago \\
3. & Lepidoptera & Ulat bulu & Larva \\
4. & Hymenoptera & Lebah pemotong daun (Megachile sp) & Imago \\
5. & Hymenoptera & Semut rangrang (Oecophylla smaragdina) & Imago \\
\hline
\end{tabular}

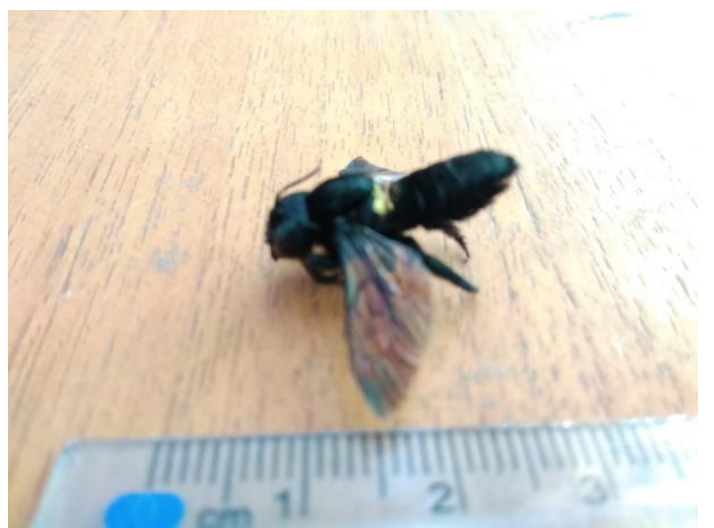

Gambar 4. Lebah Megachile sp (tampak samping)

(Figure 4. Megachile sp Bee (side view)) 


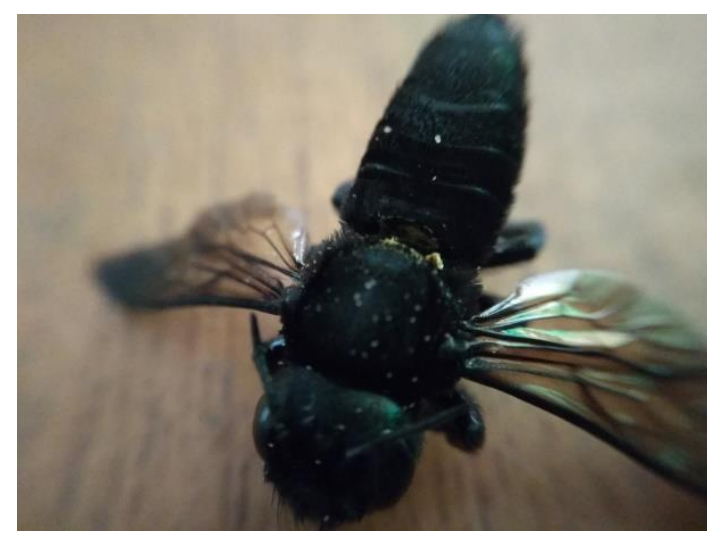

Gambar 5. Lebah Megachile sp (tampak atas)

(Figure 5. Megachile sp Bee (visible above))

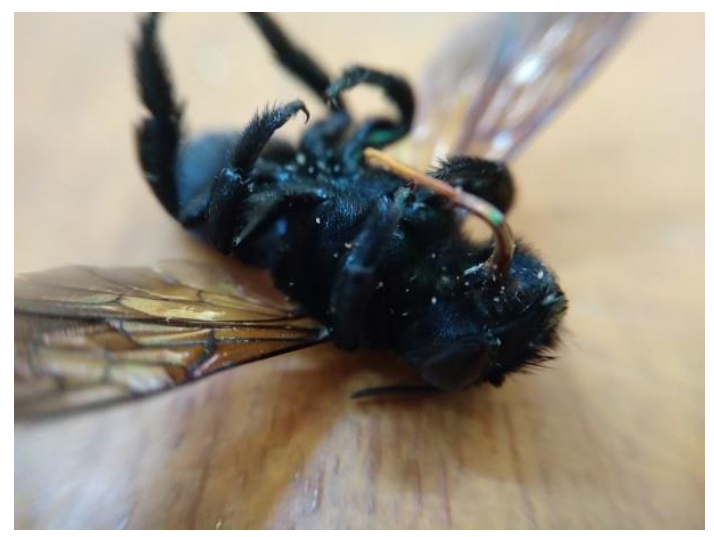

Gambar 6. Lebah Megachile sp (tampak bawah)

(Figure 6. Megachile sp Bee (visible below))

Megachile sp menyerang daun Diospyros celebica dengan cara memotong daun menggunakan mulutnya. Serangga ini aktif pada pagi, siang dan sore hari. Setiap kali serangan potongan daun yang di bawah berukuran diameter $\pm 1 \mathrm{~cm}$. Megachile sp menyerang seluruh bagian daun secara acak mulai dari tajuk bagian atas sampai bawah, dan cabang bagian tengah sampai ujung. Serangga ini membawa potongan daun tersebut ke dalam tanah yang digunakan untuk membangun sarang di dalam tanah.

Jarak sarang Megachile $\mathrm{sp}$ dengan tanaman Diospyros sp paling dekat $\pm 10 \mathrm{~m}$ dan yang paling jauh $\pm 147 \mathrm{~m}$. Hal ini menunjukkan bahwa serangga ini mempunyai daya jelajah yang cukup jauh dari sarangnya. Secara vertikal serangan serangga ini bisa mencapai $7,4 \mathrm{~m}$ yang merupakan pohon tertinggi di plot pengamatan.
Persentase ditemukannya Megachile $\mathrm{sp}$ pada tegakan $D$. celebica yaitu $97,44 \%$, dimana dari 39 pohon yang diamati serangga ini ditemukan pada 38 pohon. Besarnya frekuensi ditemukannya Megachile sp disebabkan karena serangga ini tidak memiliki predator alami.

Selain menyerang daun $D$. celebica serangga ini juga menyerang daun Diospyros rumphii dan Pometia pinata. Serangan yang dibuat mirip dengan serangan pada daun $D$. celebica. Menurut (Sulistio, et.al., 2014) dinamika populasi suatu serangga hama dipengaruhi oleh berbagai interaksi seperti tanaman inangnya, parasitoid dan predator serta kompetisi dari spesies tersebut. Serangan Megachile sp pada jenis Diospyros rumphii dan Pometia pinata dapat dilihat pada Gambar 11 dan 12. 


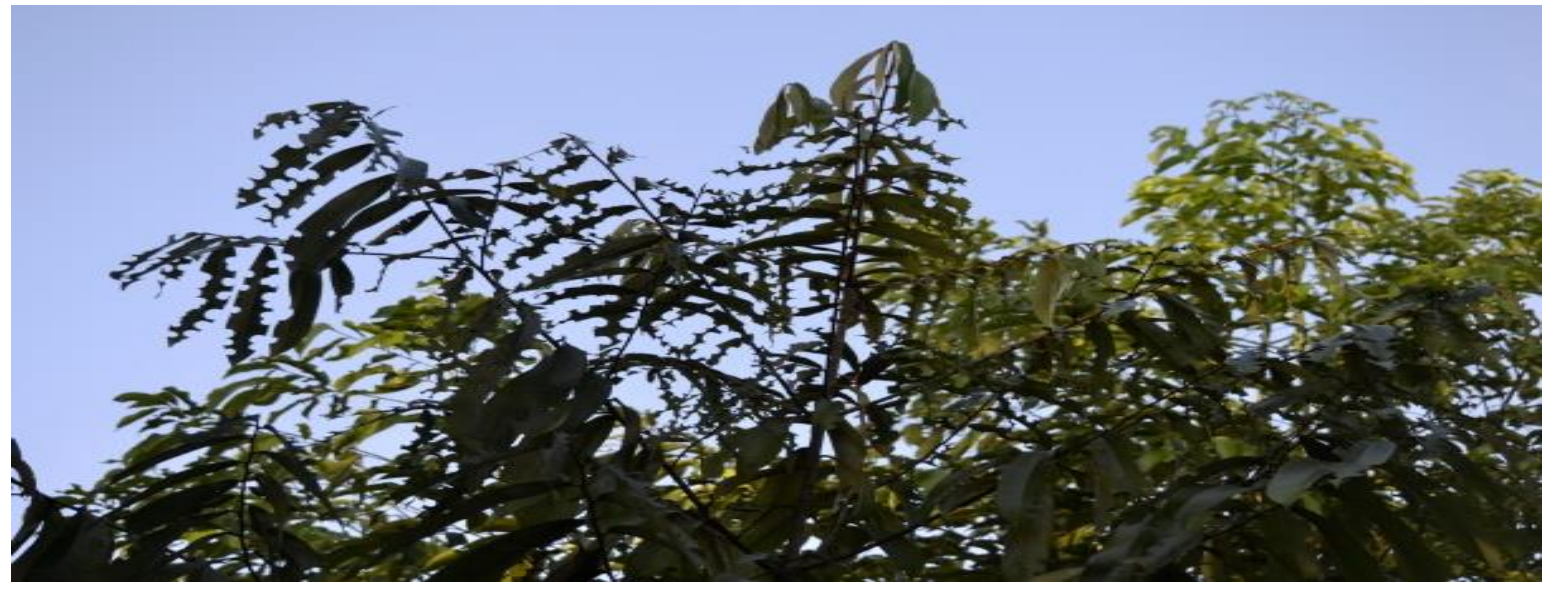

Gambar 7. Serangan Megachile sp pada Tajuk Atas Diospyros celebica

(Figure 7. Attack on Megachile sp in the Upper Canopy of Diospyros celebica)

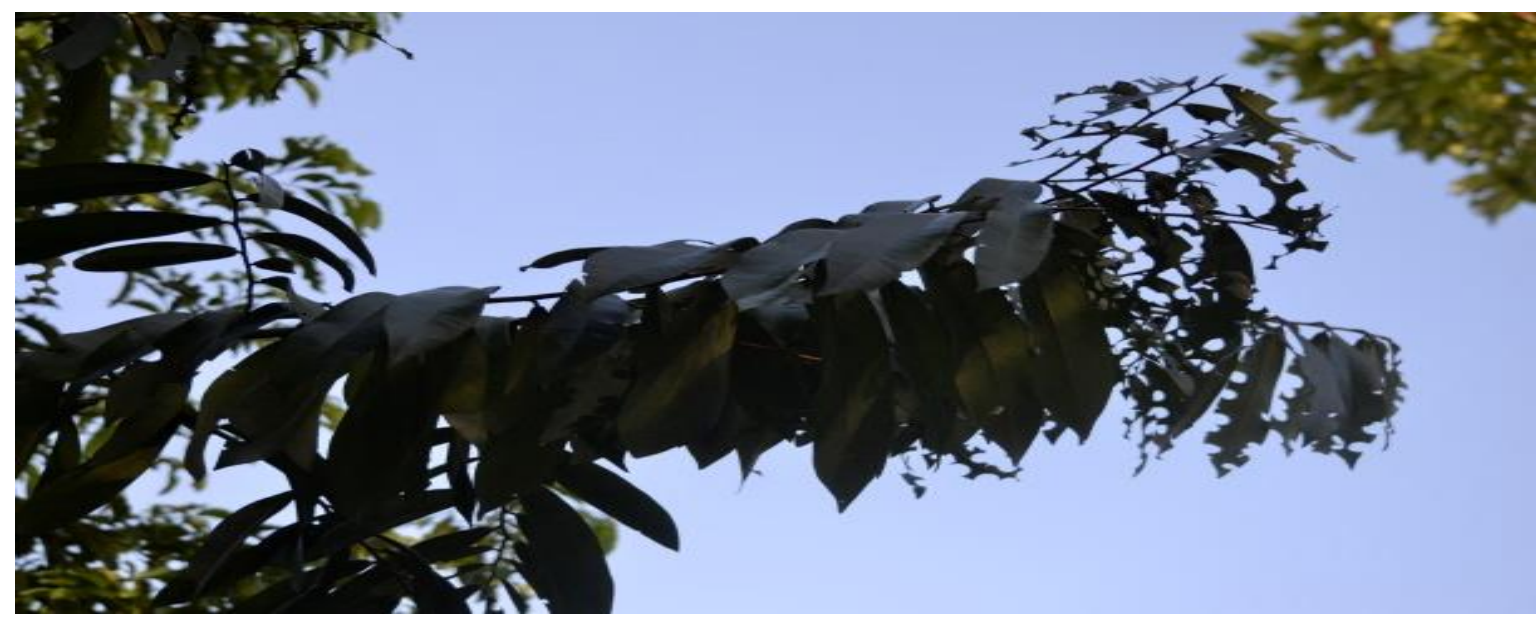

Gambar 8. Serangan Megachile sp pada Ujung Cabang Tajuk Bagian Tengah Diospyros celebica

(Figure 8. Attack on Megachile sp at the End of the Canopy Branch in the Middle of Diospyros celebica)

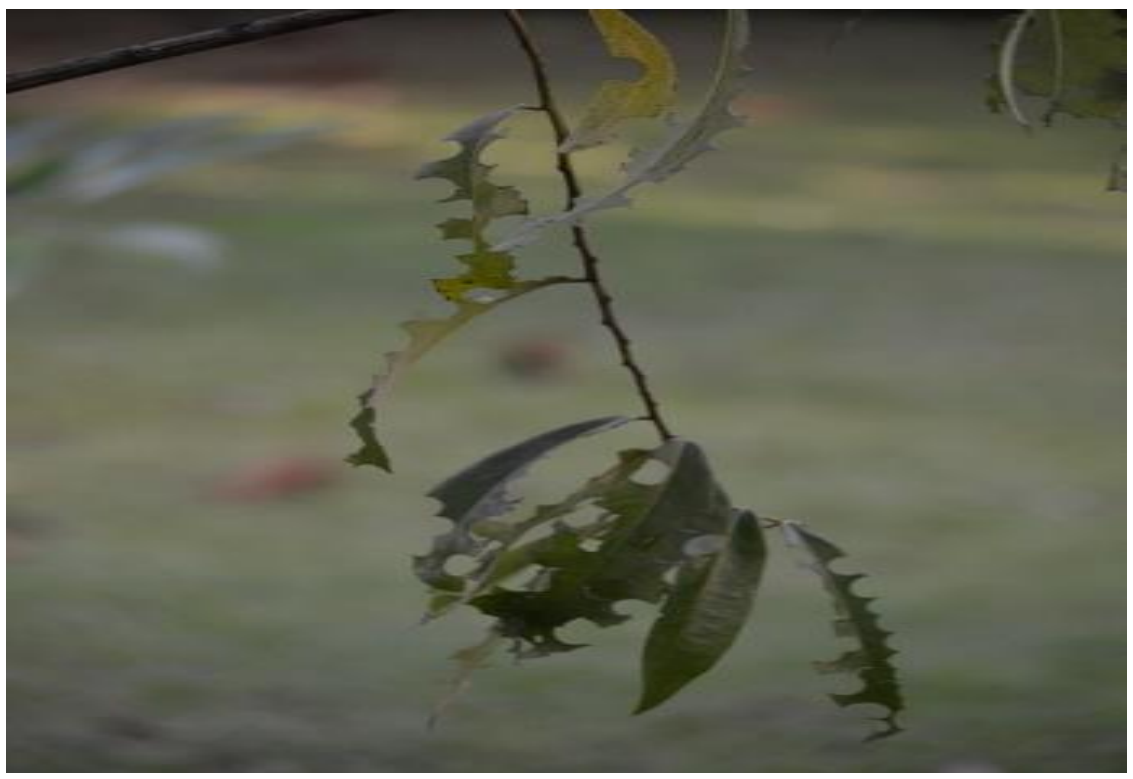

Gambar 9. Serangan Megachile sp pada Tajuk Bagian Bawah Diospyros celebica

(Figure 9. Attack on Megachile sp in the Lower Canopy of Diospyros celebica) 


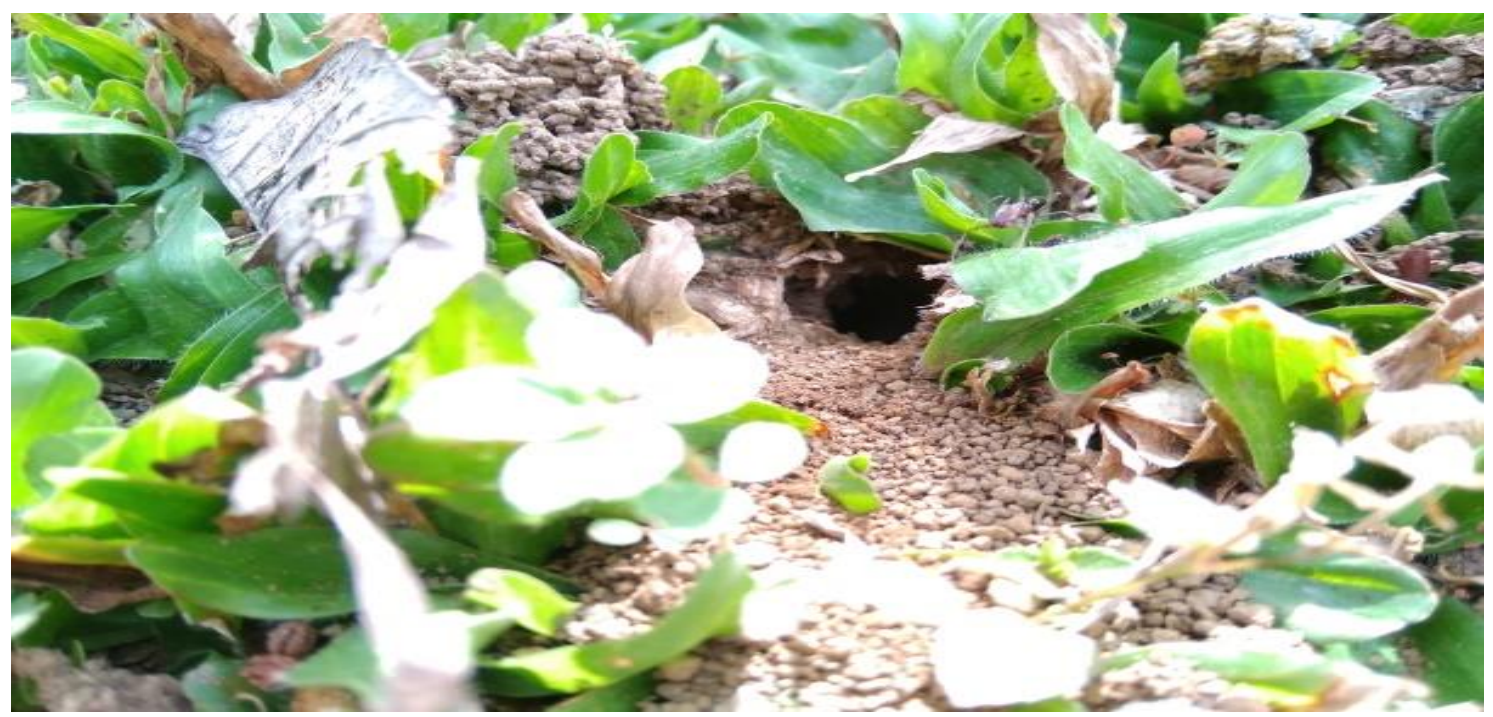

Gambar 10. Sarang Megachile sp

(Figure 10. Nest of Megachile sp)

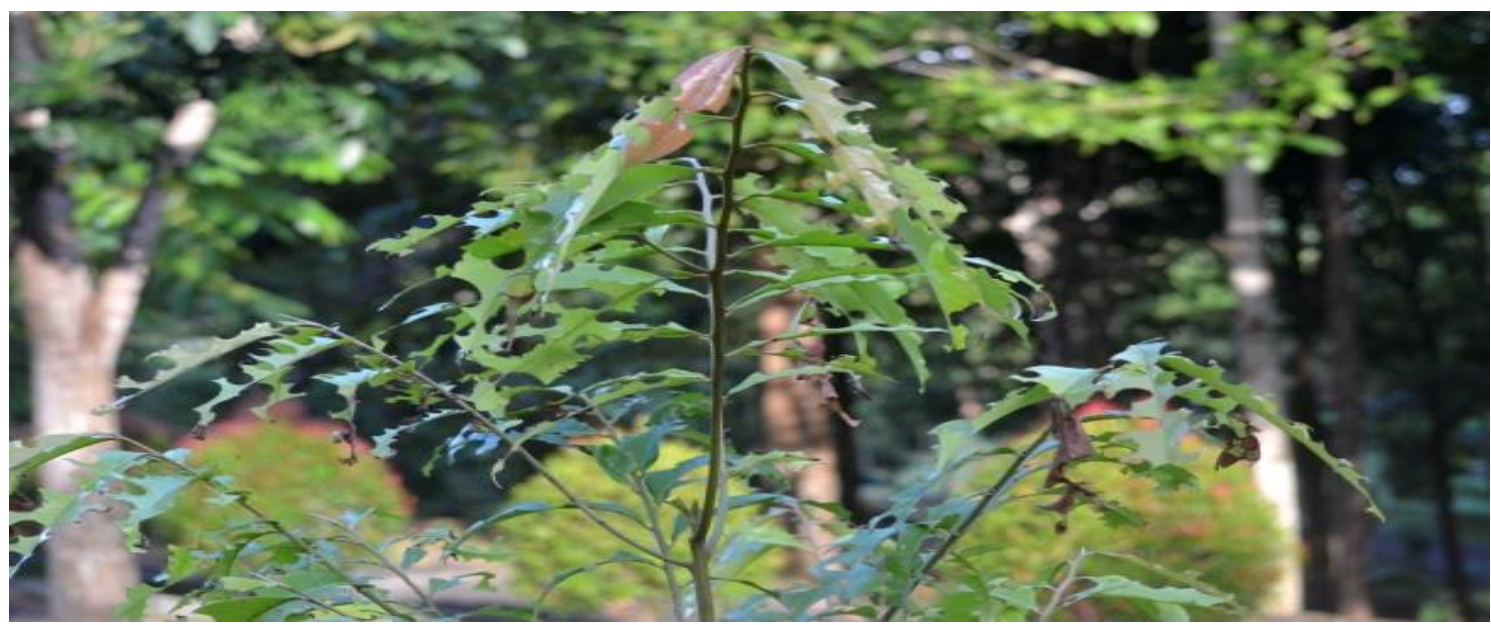

Gambar 11. Gejala Serangan Megachile sp. pada Diospyros rumphii

(Figure 11. Symptoms of Attack on Megachile sp. on Diospyros rumphii)

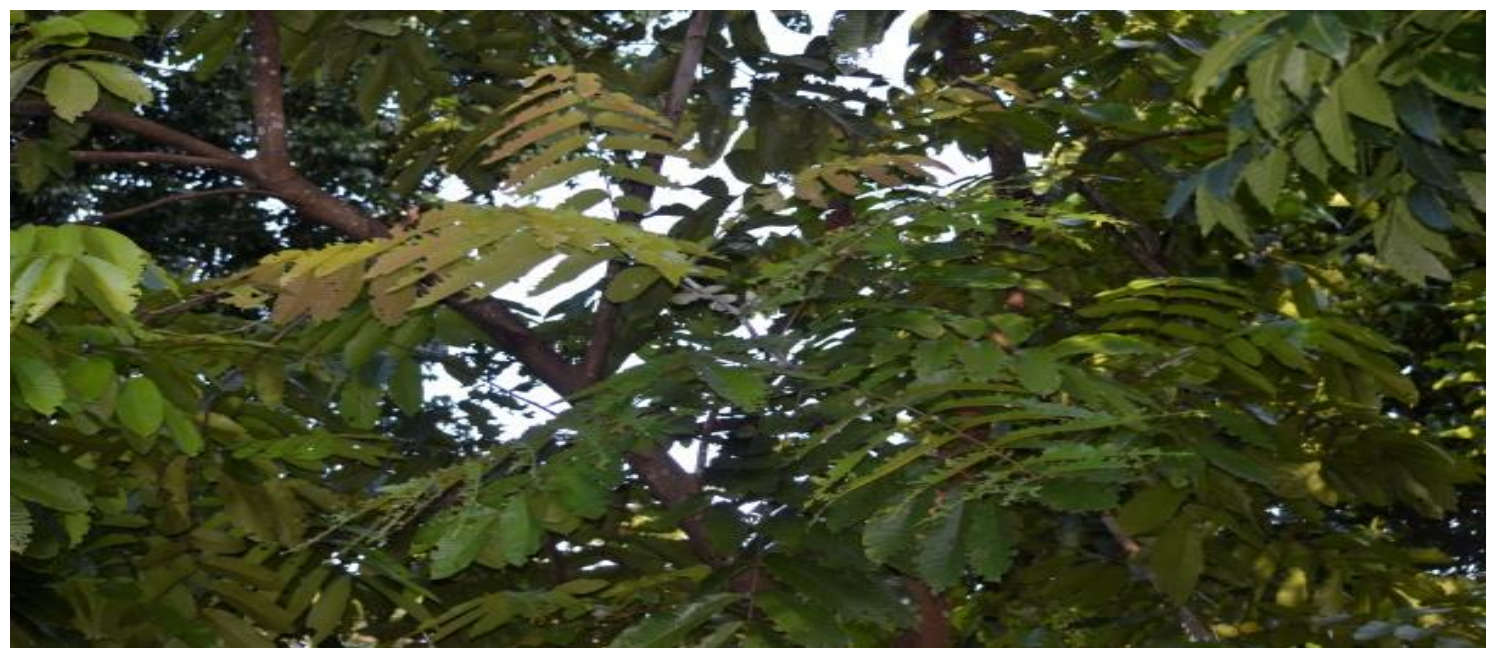

Gambar 12. Gejala Serangan Megachile sp pada Pometia pinata

(Figure 12. Symptoms of Megachile sp Attack on Pometia pinata) 
Selain sebagai hama yang merusak daun, serangga dari ordo Hymenoptera famili Megachilidae merupakan serangga penyerbuk utama pada tanaman pertanian. Kehadirannya pada lahan pertanian sangat dibutuhkan dan telah banyak dikembangkan untuk dimanfaatkan sebagai serangga penyerbuk pada berbagai negara (Widhiono, 2015).

\section{Ulat Bulu}

Klasifikasi diuraikan sebagai berikut Golongan : Animalia

$\begin{array}{lll}\text { Phylum } & : & \text { Arthropoda } \\ \text { Klas } & : & \text { Insekta } \\ \text { Ordo } & : & \text { Lepidoptera } \\ \text { Famili } & : & \text { Erebidae } \\ \text { Sub famili } & : & \text { Arctinae }\end{array}$

\section{Ciri-ciri Ulat Bulu :}

Memiliki bulu yang lebat, bulu yang tumbuh di bagian kepala lebih panjang dengan bulu pada bagian badan, panjang badan berukuran 3$3,5 \mathrm{~cm}$, bermetamorfosis menjadi ngengat.

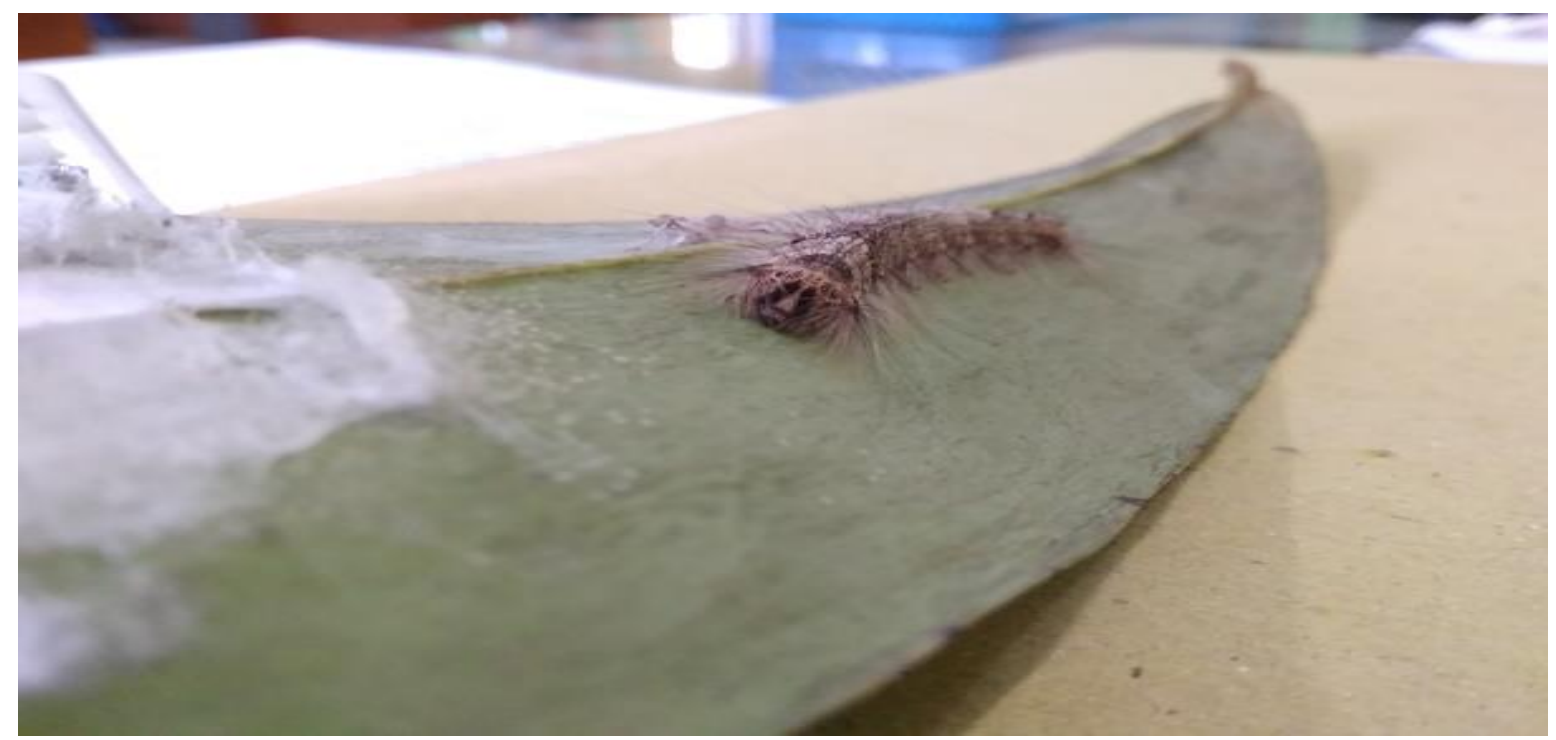

Gambar 13. Ulat Bulu (tampak depan)

(Figure 13. The Caterpillar (looks front))

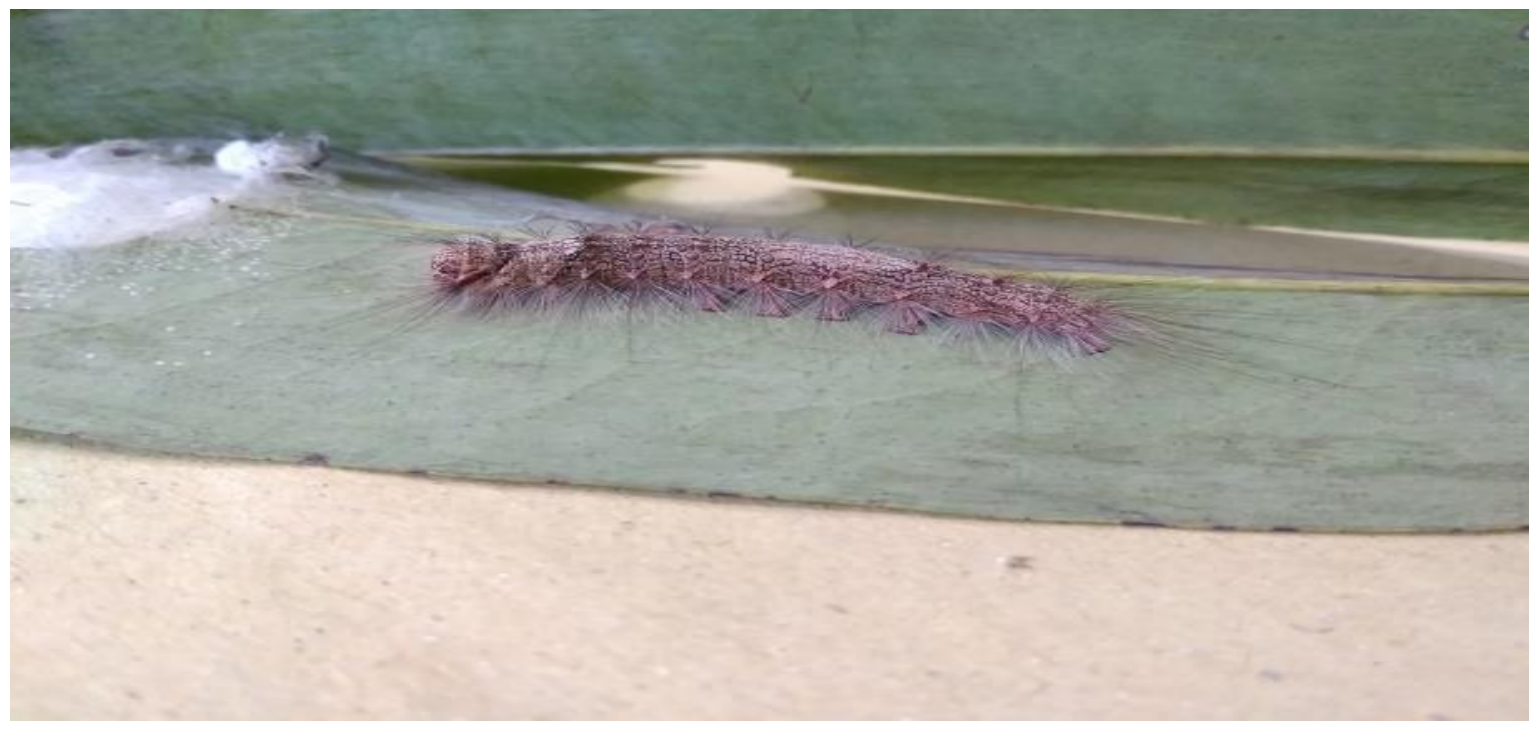

Gambar 14. Ulat Bulu (tampak samping)

(Figure 14. The Caterpillars (side view)) 
Ulat bulu menyerang daun Diospyros celebica dengan cara memakan bagian daun mulai dari tepi daun ke bagian tengah daun. Serangannya berbentuk lingkaran dengan diameter $\pm 2 \mathrm{~cm}$ dalam satu kali serangan. Larva ini aktif pada pagi, siang dan sore hari. Ulat bulu menyerang tajuk bagian tengah pada daun bagian pangkal dan tengah cabang, sampai tajuk bawah pada daun bagian pangkal dan tengah cabang.

Frekuensi ditemukannya ulat bulu pada tegakan D. celebica yaitu $7,69 \%$, dimana dari 39 pohon yang diamati ulat bulu hanya ditemukan pada 3 pohon. Hal ini disebabkan karena dalam tegakan $D$. celebica ditemukan predator alami dari ulat ini yaitu cucak kutilang (Pycnonotus aurigaster), bubut alang-alang (Centropus bengalensis), kadalan Sulawesi (Phaenicophaeus calyorhynchus), kehicap ranting (Hypothymis azurea), dan semut rangrang (Oecophylla smaragdina).

Burung bubut alang-alang dan kadalan Sulawesi adalah burung pemakan serangga, burung-burung ini menyukai pohon yang tidak terlalu tinggi dan rimbun yang digunakan sebagai tempat mencari pakan, bermain, berlindung dan bersarang (Arini, et.al., 2018). Menurut (Arifin, M dan Kasdi Subagyono, 2011) populasi ulat bulu dapat dikendalikan dengan memanfaatkan musuh alami salah satunya adalah semut rangrang. Menurut Falahudin Irham (2012), hama ulat juga ditemukan pada perkebunan kelapa sawit dan semut rangrang mempunyai peranan sebagai pengendali biologis terhadap hama ulat.

Serangan ulat bulu pernah terjadi di Probolinggo, menyebabkan daun tanaman mangga gundul. Ulat yang mendominasi di Probolinggo adalah dari keluarga Lymantriidae, dengan dua spesies yang dominan yaitu Arctornis submarginata dan Lymantria marginata. Faktor pemicu utama ledakan populasi ulat bulu di Probolinggo adalah perubahan ekosistem yang ekstrem. Perubahan tersebut dipicu oleh beberapa hal, yakni musim hujan yang panjang pada tahun 2010-2011 yang menyebabkan kenaikan kelembapan udara. Suhu yang berfluktuasi berdampak terhadap iklim mikro, abu vulkanik letusan gunung bromo, penanaman hanya satu varietas mangga, peralihan fungsi hutan dan penggunaan input kimia seperti pestisida dan pupuk (Baliadi, et.al., 2012).

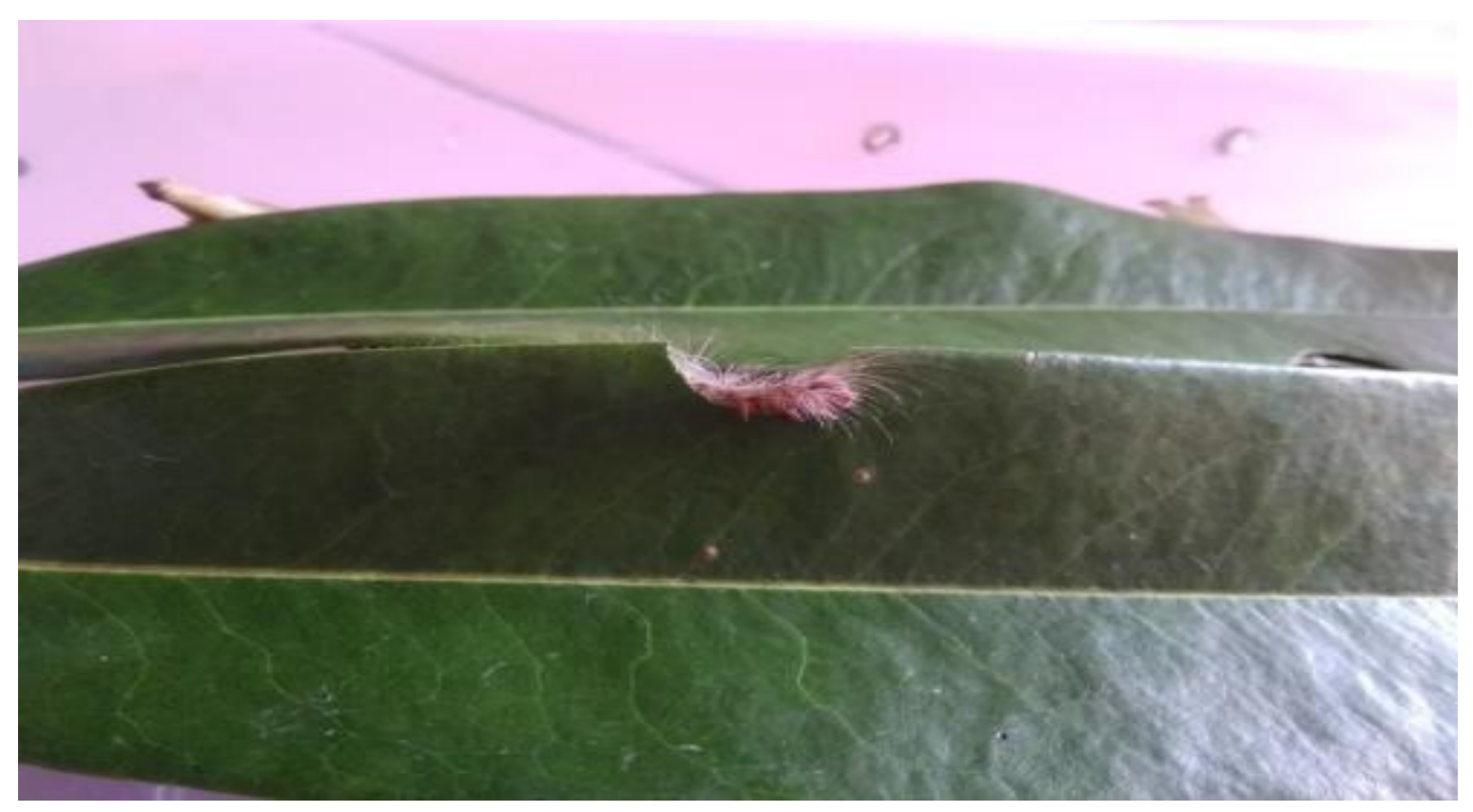

Gambar 15. Ulat Bulu Memakan Daun Diospyros celebica

(Figure 15. The Caterpillar Feeds on the Leaves of Diospyros celebica) 


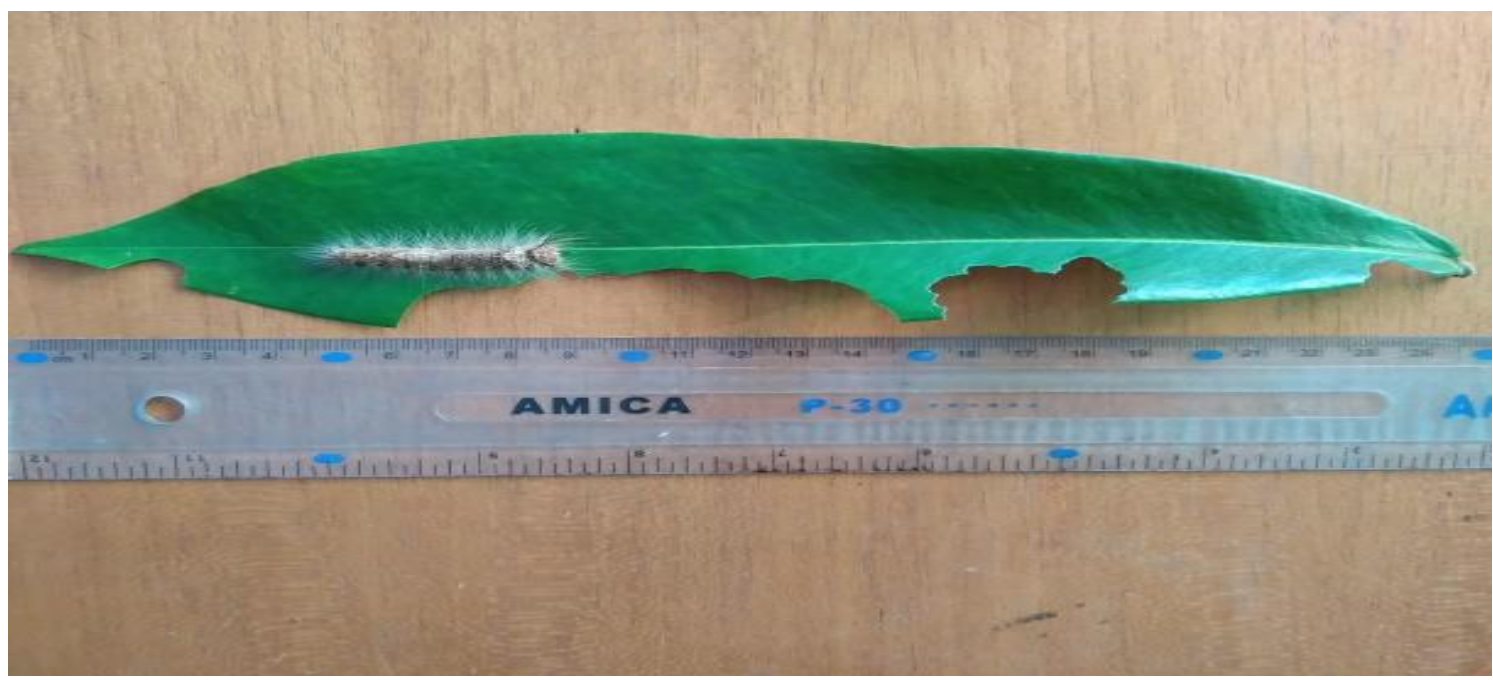

Gambar 16. Gejala Serangan ulat bulu

(Figure 16. Symptoms of Caterpillar Attacks)

\section{Pola Serangan}

Berdasarkan pengamatan pola serangan serangga pada daun Diospyros sp bersifat acak. Serangan pada daun dari tajuk bawah sampai tajuk atas dan seluruh bagian cabang dari ujung sampai pangkal cabang. Serangan paling banyak ( 36 serangan) terdapat pada tajuk bagian bawah pada daun di ujung cabang dan serangan paling sedikit pada tajuk atas bagian pangkal cabang (5 serangan).

Kerusakan pada daun jika dilihat dari tajuk atas sampai bawah secara keseluruhan bagian yang paling banyak diserang adalah daun bagian ujung cabang (daun muda). Jumlah serangan pada ujung tajuk atas (26 serangan), ujung tajuk tengah (28 serangan) dan ujung tajuk bawah (36 serangan). Bagian yang paling sedikit diserang adalah bagian daun di pangkal cabang yaitu pangkal cabang tajuk atas (5 serangan), pangkal cabang tajuk tengah (6 serangan) dan pangkal cabang tajuk bawah (12 serangan). Serangan jika dilihat pada setiap individu pohon maka serangan paling besar terdapat pada pohon nomor 39 dimana serangan pada skor 2 sampai 3 , hal ini disebabkan karena pohon tersebut ditanam terpisah jauh sedangkan pohon no 1 sampai 38 berada dalam satu tegakan.

\section{Frekuensi Serangan}

Frekuensi serangan serangga pada daun D. celebica sebesar $97,44 \%$ dari hasil perhitungan tersebut menunjukkan hampir semua pohon diserang serangga. Jumlah tanaman yang diamati sebanyak 39 tanaman dimana yang diserang serangga pada daun sebanyak 38 tanaman.

\section{Intensitas Serangan}

Dari hasil perhitungan intensitas serangan pada daun Diospyros celebica menunjukkan bahwa intensitas serangan $11,54 \%$ termasuk rusak ringan, pada kondisi ini penanggulangan hama belum perlu dilakukan karena kondisi tegakan hanya terserang rusak ringan. Hal ini sependapat dengan penelitian yang dilakukan Triwibowo, et.al. (2014) pada tegakan Shorea leprosula Miq dimana frekuensi serangan hama sebesar $91 \%$ dan intensitas serangan hama $29,5 \%$ termasuk rusak sedang. Penanggulangan hama juga belum perlu dilakukan karena kondisi tegakan hanya terserang rusak sedang. 


\section{KESIMPULAN DAN SARAN}

\section{Kesimpulan}

Berdasarkan hasil penelitian dapat ditarik kesimpulan sebagai berikut : 1) Serangga hama pada tegakan Diospyros celebica di Arboretum Balai Penelitian dan Pengembangan Lingkungan Hidup dan Kehutanan adalah lebah pemotong daun (Megachile sp) dan ulat bulu ordo Lepidoptera, famili Erebidae, sub famili Arctinae; 2) Tingkat serangan serangga pada daun Diospyros celebica sebesar $11,54 \%$ termasuk rusak ringan.

\section{Saran}

Perlu dilakukan penelitian lebih lanjut tentang pengaruh serangan serangga pada daun terhadap pertumbuhan Diospyros celebica.

Perlu dilakukan penelitian lebih lanjut tentang pengaruh lingkungan terhadap populasi Megachile sp dan ulat bulu.

\section{DAFTAR PUSTAKA}

Arifin, M., K. Subagyono. 2011. Ulat Bulu, Serangga Hama yang Mudah Dikendalikan. http://www.litbang.pertanian. go.id/berita/one/924/file/Ulat-Bulu-yangmudah-diken.pdf. 1 Desember 2018.

Arini, D.I.D., J. Kinho, M.S. Diwi, M. Christita, J.E. Halawane, M.F. Fahmi dan Y. Kafiar. 2018. Keanekaragaman Satwa Liar Untuk Ekowisata Taman Hutan Aqua Lestari, Minahasa Utara. Jurnal WASIAN Vol. 5 (1): 1-14.
Baliadi, Y., Bedjo dan Suharsono. 2012. Ulat Bulu Tanaman Mangga di Probolinggo: Identifikasi, Sebaran, Tingkat Serangan, Pemicu, dan Cara Pengendali-an. Jurnal Litbang Pertanian Vol. 31 (2) : 77-83.

Falahudin Irham. 2012. Peranan Semut Rangrang (Oecophylla smaragdina) dalam $\mathrm{Pe}-$ ngendalian Biologis pada Perkebunan Kelapa Sawit. https://core.ac.uk/download/ pdf/34212415.pdf. 1 Desember 2018.

Kinho, J. 2014. Status dan Strategi Konservasi Eboni (Diospyros rumphii Bakh.) di Sulawesi Utara. Surabaya. Seminar Nasional Biodiversitas V, 130 - 137.

Sulistio, B., Burhanuddin, dan H. Darwati. 2014. Serangga Hama Tanaman Gaharu (Aquilaria spp) di Areal Agroforestry Desa Nanga Kalan Kabupaten Melawi. Jurnal Hutan Lestari Vol. 2 (3) : 408 - 413.

Tribowo, H., Jumani, dan H. Emawati. 2014. Identifikasi Hama dan Penyakit Shorea leprosula Miq di Taman Nasional Kutai Resort Sangkima Kabupaten Kutai Timur Provinsi Kalimantan Timur. Jurnal AGRIFOR Vol XIII (2) : 175-184.

Untung, K. 2010. Diktat Dasar-dasar IImu Hama Tanaman. Yogyakarta : Fakultas Pertanian Universitas Gadjah Mada.

Widhiono Imam. 2015. Strategi Konservasi Serangga Pollinator. Universitas Jenderal Soedirman. Purwokerto. 